\title{
PERAN YAYASAN PENYANDANG CACAT MANDIRI SEBAGAI PENDAMPING DALAM PEMBERDAYAAN KELOMPOK DIFABEL DI BIDANG EKONOMI KREATIF
}

\author{
Yulia Ratna Sari ${ }^{1}$, Pudjo Suharso ${ }^{1}$, Sukidin ${ }^{1}$ \\ ${ }^{1}$ Program Studi Pendidikan Ekonomi, Fakultas Keguruan dan Ilmu Pendidikan, Universitas Jember \\ e-mail: yuliaratnasari93@gmail.com
}

\begin{abstract}
Abstrak
Penelitian ini bertujuan untuk mengetahui peran Yayasan Penyandang Cacat Mandiri Yogyakarta terhadap pemberdayaan kelompok difabel dalam bidang ekonomi kreatif. Jenis penelitian yang digunakan adalah deskriptif kualitatif. Tempat penelitian di Yayasan Penyandang Cacat Mandiri yang berada di Jalan Parangtritis Km 7, Dusun Cabean, Desa Panggungharjo, Kecamatan Sewon, Kabupaten Bantul, Yogyakarta. Informan utama yang digunakan dalam penelitian ini adalah 5 orag dengan ciri informan aktif minimal tiga tahun dan telah diberdayakan. Informan tambahan adalah lima orang karyawan YPCM. Metode pengumpulan data meliputi observasi, wawancara dan dokumen. Analisis data menggunakan deskriptif kualitatif dangan langkah analisis yaitu pengumpulan data, transkip data, pengambilan kesimpulan sementara, triangulasi dan kesimpulan akhir. Hasil penelitian dapat disimpulkan bahwa peran Yayasan Penyandang Cacat Mandiri sebagai pendamping dalam pemberdayaan kelompok difabel di bidang ekonomi kreatif yaitu sebagai motivator dan fasilitator. Peranan sebagai motivator yaitu memberikan berbagai macam bentuk dorongan yang mampu memberi energy positif dan dapat membangkitkan kepercayaan diri difabel. Peranan sebagai fasilitator yaitu memberikan memberikan pelatihan dan mewadahi kemampuan difabel setelah mengikuti pelatihan seperti turut menghasilkan nilai jual produk ekonomi kreatif untuk membantu ekonomi mereka.
\end{abstract}

Kata Kunci: Difabel, pemberdayaan, ekonomi kreatif

\section{PENDAHULUAN}

Disabilitas seringkali dianggap sebagai kendala untuk mengakses pembangunan sehingga dibutuhkan pemberdayaan dalam arti sempit: kedermawanan, dan bukan pada pemenuhan hak-hak dasar kelompok difabel. Segala bentuk keterbatasan fisik membuat kebanyakan masyarakat berpikiran bahwa kelompok difabel tidak mampu melakukan pekerjaan sebagaimana yang biasa dilakukan oleh orang-orang 'normal'. Selain itu, mereka masih menganggap bahwa kelompok difabel lebih baik disantuni daripada diberdayakan sehingga hal ini membuat penyandang disabilitas kehilangan kesempatan untuk mendapat akses pendidikan dan pekerjaan yang lebih layak.

Stigma-stigma negatif tentang kecacatan juga membuat para penyandang disabilitas mundur dari lingkungan orang-orang 'normal'. Keinginan untuk berbaur melakukan segala macam aktivitas seperti manusia pada umumnya akhirnya hanya menjadi angan-angan belaka, karena banyak dari mereka merasa malu dan tidak percaya diri dengan kondisi tubuhnya. Pada umumnya, dukungan dari lingkungan sekitar bahkan orang terdekat seperti keluarga juga sangat minim. Jika salah satu anggota keluarga mengalami kecacatan, tak sedikit yang menutup-nutupi, menyembunyikan atau bahkan tidak menerima.Berbagai kendala yang dialami oleh penyandang disabilitas terkadang memunculkan kekhawatiran dari pihak keluarga, banyak penyandang disabilitas yang hanya berdiam diri di dalam rumah. Hal tersebut menyebabkan perkembangan sosialnya menjadi lemah karena mereka secara terus-menerus menggantungkan hidup pada anggota keluarga yang lain.

Selain itu, ruang-ruang publik yang tidak aksesibel juga menyulitkan penyandang disabilitas untuk bergerak sehingga mobilitas mereka menjadi sangat lambat dan terbatas.Sekali pun ada beberapa sekolah, perguruan tinggi dan perusahaan yang mau menerima dan memberi kesempatan, namun penyandang cacat tidak bisa optimal memanfaatkan kesempatan tersebut.Sarana belajar, komunikasi, kendaraan, ruang yang tersedia masih tidak aksesibel bagi mereka.Tidak adanya bidang miring dan tangga yang terlalu tinggi pada bangunan sekolah atau perusahaan misalnya, hal tersebut membuat penyandang tuna daksa atau penyandang tuna netra 
kesulitan untuk bergerak. Padahal mengenai penyediaan aksesibilitas sebenarnya telah diatur dalam UndangUndang No. 4/ 1997 tentang penyandang cacat, bab 1 pasal 1 ayat 4, yang berbunyi "aksesibilitas adalah kemudahan yang tersedia bagi penyandang cacat guna mewujudkan kesamaan kesempatan dalam segala aspek kehidupan dan penghidupan." Namun lagi-lagi, kenyataannya hal tersebut tidak benar-benar diimplementasikan.

Meskipun begitu, adanya berbagai bentuk penolakan tak menjadikan sebagian dari mereka patah semangat.Jika dilihat dari sudut pandang berbeda, kaum difabel sebenarnya juga mampu hidup mandiri, melakukan pekerjaan seperti masyarakat 'normal' pada umumnya.Kini banyak organisasi-organisasi nirlaba atau kelompok-kelompok difabel yang mampu menyelenggarakan pemberdayaan bagi kaum difabel.Organisasi independen seperti Yayasan Penyandang Cacat Mandiri (YPCM) misalnya, mereka mampu mengupayakan kesejahteraan bagi penyandang disabilitas dan mampu berkecipung di dunia ekonomi kreatif. Kecilnya kesediaan masyarakat memberi kesempatan kepada penyandang disabilitas untuk bekerja tak menyurutkan semangat difabel di Yogyakarta untuk membentuk satu kelompok yang mampu menunjukkan kreativitas dan kemandirian mereka. Pada tahun 2003 mereka membentuk kelompok bernama Mandiri Craft yang beranggotakan 10 orang difabel usia produktif. Mereka membuka bengkel kerja yang memproduksi produk kreatif berupa barang-barang kerajinan dan dimanajeri oleh anggota mereka yang juga seorang difabel.Sepanjang 2003-2006 mereka memproduksi produk-produk kreatif dan menerima pesanan dari berbagai wilayah di dalam maupun luar negeri. Meski pernah dilanda gempa dan workshop mereka hancur, pada tahun 2007 mereka bangkit kembali membentuk sebuah Lembaga Swadaya Masyarakat bernama Yayasan Penyandang Cacat Mandiri (YPCM) untuk mendukung aspek hukum.

Menurut Payne (1997) dalam Adi (2003) Pemberdayaan adalah:"membantu klien memperoleh daya untuk mengambil keputusan dan menentukan tindakan yang akan ia lakukan yang terkait diri mereka, termasuk mengurangi efek hambatan pribadi dan social dalam melakukan tindakan. Hal ini dilakukan melalui peningkatan kemampuan dengan rasa percaya diri untuk membentuk masa depan sesuai dengan keinginan mereka".

Tesoriero (2008:558) menyebutkan terdapat tiga peran dan keterampilan dalam melakukan pemberdayaan, diantaranya:

1. Peran memfasilitasi adalah yang berkaitan dengan stimulasi dan penunjang pemberdayaan masyarakat. Dimana terdapat beberapa kategori peran memfasilitasi, antara lain: semangat social; mediasi dan negosiasi; dukungan; membangun consensus; fasilitasi kelompok, pemanfaatan berbagai keterampilan dan sumber daya,;mengorganisasi; dan komunikasi pribadi.

2. Peran mendidik dimana berperan aktif sebagai agen yang memberikan masukan positif dan direktif berdasarkan pengetahuan dan pengalamannya. Dimana terdapat beberapa kategori peran, diantaranya: peningkatan kesadaran; memberikan informasi mengenai berbagai sumber eksternal; pelatihan;

3. Peran representasi digunakan untuk menunjukkan berbagai peran dalam masyarakat untuk berinteraksi dengan pihak luar demi kepentingan masyarakat. Beberapa kategori peran tersebut antara lain: memperoleh berbagai sumber daya dalam membantu sebuah masyarakat untuk memperoleh berbagai sumber informasi, ketrampilan dan keahlian yang dibutuhkan agar mampu mendirikan berbagai struktur sendiri dan menemukan tujuan sendiri; advokasi; menggunakan media; humas; jaringan kerja dan menyampaikan berbagai ide atas pengetahuan dan pengalaman yang didapat.

Yayasan Penyandang Cacat Mandiri (YPCM) beranggotakan 19 orang difabel.Yayasan ini bergerak memperjuangkan kesetaraan, kesejahteraan serta berupaya meningkatkan kemandirian dan potensi kaum difabel.Sejak dibentuknya, Yayasan Penyandang Cacat Mandiri (YPCM) telah mampu mendorong penyandang disabilitas untuk berkarya dan menciptakan lapangan kerja baru bagi mereka.YPCM juga menjadi wadah bagi beberapa korban gempa yang kehilangan pekerjaan. YPCM berupaya membantu memotivasi dan menumbuhkan semangat hidup serta kepercayaan diri setiap anggotanya.Karena kepercayaan diri itulah kemudian muncul ideide kreatif serta keberanian dari mereka untuk menciptakan produk kerajinan dengan desain unik yang tak kalah saing dengan produk buatan pabrik.

Dalam proses pemberdayaannya, YPCM melakukan banyak bentuk pelatihan, namun lebih terfokus pada pemberian pelatihan cara mengelola kayu dan membuat permainan edukatif karena usaha yang mereka kembangkan sendiri adalah memproduksi berbagai macam kerajinan berbahan dasar kayu. Hingga kini, mereka telah menciptakan dan memproduksi ratusan jenis produk, seperti diantaranya alat permainan edukasi, dekorasi 
rumah, furniture berbahan dasar kayu dan sebagainya. Produk mereka pun telah memasuki pasar luar seperti Spanyol, Australia dan New Zealand. Pemasaran produk mereka lakukan dengan berbagai cara, yakni melalui sistem online, titip jual (konsinyasi) di toko-toko sekitar Yogyakarta maupun dijual langsung di show room yang berada di area gedung YPCM. Omzet rata-rata yang mereka dapatkan pun terbilang lumayan. Mereka bisa mengantongi hingga Rp 20.000.000 setiap bulannya.Keberanian serta tekad telah menjadikan mereka manusia yang lebih mandiri, produktif dan dapat memperbaiki kehidupan ekonominya. Berikut hasil wawancara dengan salah seorang karyawan Yayasan Penyandang Cacat Mandiri:

"Saya pertama kali datang ke sini dari nol, sama teman-teman bagian produksi diajari dari nol. Saya termotivasi bagaimana caranya supaya harus bisa bekerja.Akhirnya yayasan ini mau menampung saya, dan itulah kesempatan saya untuk belajar." (DY, 29 tahun)

Hasil wawancara di atas menunjukkan adanya peran yayasan dalam mewujudkan kemandirian difabel untuk berkarya dan menjadi manusia yang produktif.

Berdasarkan uraian tersebut di atas, maka peneliti tertarik untuk melakukan penelitian dengan judul "Peran Yayasan Penyandang Cacat Mandiri Sebagai Pendamping Dalam Pemberdayaan Kelompok Difabel di Bidang Ekonomi Kreatif (Studi Kasus di Yayasan Penyandang Cacat Mandiri, Sewon, Bantul, Yogyakarta)”. Berdasarkan rumusan masalah, maka tujuan penelitian ini adalah untuk mendeskripsikan peran Yayasan Penyandang Cacat Mandiri Yogyakarta terhadap pemberdayaan kelompok difabel dalam bidang ekonomi kreatif

\section{METODE PENELITIAN}

Penelitian ini dirancang sebagai penelitian deskriptif dengan pendekatan kualitatif untuk mendeskripsikan peran Yayasan Penyandang Cacat Mandiri Yogyakarta terhadap pemberdayaan kelompok difabel dalam bidang ekonomi kreatif.

Informan utama yang digunakan dalam penelitian adalah 5 orang dengan ciri informan aktif minimal tiga tahun dan telah diberdayakan. Informan tambahan adalah lima orang karyawan YPCM.

Metode pengumpulan data yang digunakan peneliti terdiri dari observasi, wawancara dan dokumen. Analisis data menggunakan deskriptif kualitatif dangan langkah analisis yaitu pengumpulan data, transkip data, pengambilan kesimpulan sementara, triangulasi dan kesimpulan akhir.

\section{HASIL PENELITIAN Hasil Penelitian}

Peran Yayasan Penyandang Cacat Mandiri sebagai pendamping dalam pemberdayaan kelompok difabel di bidang ekonomi kreatif yaitu sebagai motivator. Sebagai motivator, YPCM berusaha membangkitkan keyakinan atau kekuatan yang selama ini terpendam dalam diri tiap anggotanya sehingga dapat membangunkan rasa percaya diri. Seperti yang diungkapkan oleh salah seorang informan yang merupakan ketua pengurus YPCM saat wawancara berikut;

\footnotetext{
"Saya gabung dengan YPCM sejak 2013, saya memilih bergabung karena bersifat pribadi karena memang bergabung disini ini membutuhkan kebesaran hati, kebesaran jiwa karena terus terang kami di sini lebih banyak untuk melayani, bagi orang yang tidak punya jiwa melayani pasti nggak akan tahan di sini. Mereka bagaimana pun saya kepengin agar bisa menikmati hidup seperti yang dirasakan oleh kita-kita yang normal. Semoga dengan saya di sini sedikit banyak bisa mewujudkan keinginan-keinginanmereka,bisa membuat mereka bersemangat.Perlu diingat bahwa di Yayasan Penyandang Cacat Mandiri para penyandang disabilitas tidak membutuhkan belas kasian tetapi mereka ingin menemukan sebuah jati diri. Kalau saya di sini ini kan hanya memotivasi supaya mereka itu jangan rendah diri, supaya jangan patah semangat saya dorong mereka untuk bangkit dari rasa-rasa itu karena sejauh mereka diberi kepercayaan dan diasah skillnya, mereka itu mampu kok "
}

Sebagai motivator, pada proses pendampingan ini anggota YPCM yang telah senior atau memiliki pengalaman lebih lama mencoba menggali potensi sumber daya yang dimiliki oleh rekan-rekan difabel yang baru bergabung atau belajar. Kemudian mereka mengembangkan kesadaran diri tiap anggotanya agar dapat terbuka terhadap permasalahan yang dihadapi. Selain itu, sebagai pendamping, anggota yang telah senior juga menjadi komunikator, mereka menjadi tempat untuk berbagi informasi dan mampu membantu rekan difabel 
melaksanakan berbagai program atau pekerjaan di yayasan. Anggota YPCM juga menjadi fasilitator yang mendampingi rekan difabel dengan melakukan pengarahan seperti membantu dalam proses produksi produk kreatif dengan mengenalkan cara-cara penggunaan alat dan mengajari teknik-teknik membuat kerajinan. Apabila rekan difabel mengalami kesulitan, setiap anggota yayasan selalu mendiskusikannya dan saling membantu satu sama lain.

Motivasi dan dukungan moral yang diberikan oleh YPCM juga dirasakan sangat bermanfaat oleh tiap anggotanya. Informan C (39 tahun) dan F (55 tahun) mengutarakan bahwa dirinya menjadi lebih semangat dan lebih membuka pikiran positif ketika bergabung dengan yayasan. Informan F (55tahun) mengatakan bahwa:

"Sejak gempa dan saya cacat itu saya trauma, kan dulunya saya normal.Setelah gempa itu saya gabung di sini, ketemu mbak-mbak, mas-mas menyenangkan sudah seperti keluarga.Jadi saya sudah ndak sedih kaya dulu lagi.Dulu waktu masih normal saya cuma ibu rumah tangga, alhamdullilah Allah memberikan saya pekerjaan di sini, malah jadi punya kegiatan, bisa membantu suami cari uang juga. Saya senang betah di sini” (F, 55 tahun)

Serupa dengan yang dikatakan informan F (55 tahun), informan C (39 tahun)juga merasakan banyak perubahan dalam dirinya. Informan menuturkan pada peneliti:

"Saya sebelum di sini, kerja tas kulit di Manding, terus pernah juga kerajinan pandan di Tembi tapi cuma sebentar. Di sini saya lebih nyaman, kalau dulu di tempat saya kerja kan semuanya normal, suasananya kurang mendukung jadi saya dulu sering minder. Ruangan kerjanya kan di sini juga lebih aksesibel, teman-teman juga semua baik mau membantu, ya saya banyak dibimbing lah di sini ini. Sekarang sudah ndak minder minder lagi"'(C, 39 tahun)

Dukungan moral atau motivasi yang YPCM berikan dapat berupa terapi moral untuk menyadarkan penyandang disabilitas. Seperti dikatakan oleh informan D (38 tahun) yang biasa turut serta memotivasi rekanrekan difabel, menuturkan bahwa:

\footnotetext{
"Teman-teman itu kan pas pertama dateng ke sini banyak yang cerita kalau ndak percaya diri, minder gitu.Ya, biasanya kita-kita yang sudah duluan kerja ngomong ke mereka untuk bisa bersaing dan diterima di luar kita ya harus membuktikan kalau kita ini juga punya nilai lebih. Nilai lebih itu ya salah satunya bisa kita dapat dari pendampingan di sini, kita semua kan dilatih jadi ya otomatis belajar, jadi punya keterampilan. Saya dulu malah minder banget, mbak sampai kan saya itu malu dulu sekolah biasa mau nerusin SMA itu ndak berani jadi cuma sampai SMP mau kerja juga dulu malu karena mesti ndak keterima. Sehabis magang di sini itu saya jadi terinspirasi temen yang lain, ngelihat mereka kok bisa ya saya jadi terus nyoba-nyoba belajar, termasuk suami saya itu kan juga kerja di sini lebih dulu, dia sangat mendukung"(D, 38 tahun)
}

Dari penuturan semua informan di atas dapat diketahui bahwa proses motivasi merupakan satu langkah penting dalam proses pemberdayaan, dimana proses motivasi yang dilakukan oleh rekan pendamping tersebut dirasakan mampu memberi energy positif yang kemudian dapat membangkitkan kepercayaan diri mereka.

Selain sebagai pendamping, pihak YPCM juga memberikan pelatihan. Pelatihan merupakan salah satu bentuk pemberdayaan yang sangat diutamakan karena diharapkan mampu memberdayakan penyandang disabilitas di YPCM. Pelatihan ini merupakan proses dengan serangkaian upaya yang dilaksanakan pada calon anggota atau tenaga kerja yang bertujuan untuk meningkatkan kemampuannya guna meningkatkan produktivitas dan efektivitas dalam melakukan suatu pekerjaan.

Beberapa jenis pelatihan yang dilakukan yaitu pelatihan menjahit dan keterampilan bahasa inggris khususnya, lebih diutamakan pada mereka yang belum pernah mendapat pelatihan sama sekali sebelumnya. Bentuk pelatihan ini biasanya diberikan pada penyandang disabilitas yang dititipkan oleh lembaga-lembaga yang bekerjasama dengan YPCM maupun oleh keluarganya. Sedangkan bagi penyandang disabilitas yang sedang magang dan sebelumnya sudah pernah mendapat pelatihan di tempat lain, mereka lebih diarahkan ke dalam usaha milik YPCM. Namun, apabila mereka ingin mengikuti jenis pelatihan yang berbeda juga diperbolehkan.

Tenaga ahli yang memberikan pelatihan pada para penyandang disabilitas yang sedang melakukan magang atau pada calon anggota adalah mereka orang-orang yang berasal dari yayasan itu sendiri. Sebagian besar tenaga ahli tersebut juga seorang difabel dan ada beberapa non difabel yang turut membantu monitoring saat proses pelatihan maupun pada saat proses produksi berlangsung. Pelatihan tersebut semuanya dilakukan di area gedung Yayasan Penyandang Cacat Mandiri. 
Pelatihan awal yang diberikan oleh YPCM dilakukan selama kurang lebih dua hingga tiga bulan. Pada umumnya, mereka yang mengikuti pelatihan pembuatan mainan edukatif oleh yayasan kemudian diminta untuk bergabung menjadi anggota atau sebagai pekerja tetap untuk usaha kreatif yang sedang dijalankan. Seperti yang diungkapkan oleh informan $\mathrm{G}$ (59 tahun) berikut ini:

"Saya masuk sini itu 2009 bareng Pak Mardi, dulu bareng masuk sini karena kan kenagempa,terusdirekomendasikan sama LSM Karinakas itu untuk ikut training di sini. Pelatihan di sini dulu ya buat kayu itu tiga bulan. Sebelumnya saya kan kerja di perusahaan timbangan dari mulai 1975 sampai 2006 itu. Nah, 2006 itu kan gempa saya patah tulang belakang ya gak bisa apa-apa. Ya, alhamdullilah setelah ikut training saya diminta untuk kerja di sini, ya sudah saya terus kerja di sini buat buat kayu gini sampai sekarang. Daripada nganggur juga di rumah, habis gempa itu saya ndak bisa ngapa-ngapain kan. Mau kerja di tempat lain juga sudah sulit, ndak diterima. Ya, lumayan lah kerja di sini saya jadi tetap dapat penghasilan, jadi tetap bisa hidup mandiri” (G, 59 tahun).

Tawaran untuk bergabung menjadi anggota atau pekerja tetap yang dilakukan oleh pendamping dan pihak YPCM merupakan salah satu bentuk apresiasi terhadap rekan-rekan sesama difabel yang telah mengikuti serangkaian pelatihan. Dengan adanya ajakan untuk bekerja maka dapat membangkitkan semangat dan kepercayaan diri mereka karena penyandang disabilitas tersebut merasa dirinya diterima dan diakui kemampuannya. Informan J (31 tahun) menuturkan:

"Saya pertama kali datang ke sini bener-bener dari nol, dari sama sekali tidak bisa terus akhirnya sama tementemen di bagian produksi saya diajari alat-alat satu-persatu terus akhirnya sampe sekarang alhamdullilah bisa.Karena pertama motivasi saya itu gimana caranya harus bisa kerja dan akhirnya yayasan ini mau menampung saya dan itulah kesempatan saya untuk belajar.Harapan saya untuk teman-teman difabel yang saat ini belum bisa menerima diri dan cenderung minder supaya semangat dan mau berusaha".(J, 31 tahun)

Pihak YPCM mengharapkan setelah penyandang disabilitas mengikuti pelatihan adalah agar mereka dapat hidup mandiri, sejahtera dan memiliki rasa semangat serta mau bekerja. Peserta hasil dampingan YPCM yang selesai mengikuti pelatihan saat magang dan tidak ikut bergabung menjadi anggota/ tenaga kerja oleh pihak yayasan kemudian dikembalikan pada lembaga-lembaga yang menitipkan mereka. Sedangkan bagi mereka yang memilih untuk bergabung menjadi anggota tetap YPCM, selanjutnya terus mengikuti program nyata yang dikerjakan oleh yayasan.

Usaha yang saat ini dijalankan YPCM merupakan usaha yang telah lama mereka geluti bahkan sebelum yayasan ini berdiri, dahulu usaha pembuatan kerajinan berbahan dasar kayu ini bernama mandiri craft. Saat ini produk yang dihasilkan oleh YPCM jumlahnya sudah ratusan jenis alat permainan edukasi. Semua produk yang dibuat oleh YPCM kebanyakan didesain oleh tim produksi dan sebagian lagi merupakan desain dari customer sendiri.

Selain produk kreatif hasil karya sendiri, YPCM juga menerima custom order. Konsumen yang datang dapat memesan produk sesuai desain yang diinginkannya.Produk custom order yang biasa dipesan oleh konsumen yaitu diantaranya produk-produk furniture, hiasan rumah, atau benda-benda lain berbahan dasar kayu.

Produk lain yang pernah dihasilkan YPCM ternyata tidak hanya berbahan dasar kayu saja, informan I (36 tahun) yang berpengalaman ikut pelatihan menjahit dan pernah bekerja di konveksi mengatakan, produk yang dibuat juga sebagian menggunakan bahan tekstil. Namun karena peminat produk dengan bahan dasar kayu lebih banyak, sekarang sudah tidak terlalu sering memproduksi kerajinan berbahan tekstil.

"Dulu itu kan sebenarnya saya dapat pelatihan jahit, terus juga sempat kerja di konveksi ya waktu itu saya cobacoba buat mainan atau hiasan juga dari kain flannel sama perca-perca yang sudah ndak terpakai. Tapi karena sekarang ini peminatnya lebih ke kayu ya sekarang di sini fokus buat mainan edukasi itu, kalau sekarang ini saya di bagian fininising, kadang ya bantu ngamplas itu. Di sini teman-teman saling bantu"(I, 36 tahun)

Untuk pemasaran produk selain dijual melalui showroom yang juga berada di area gedung YPCM, produk yang mereka buat juga dititipkan di toko-toko sekitar Yogyakarta dengan system konsinyasi. Untuk produk yang dipasarkan ke luar pulau pada umumnya memang sudah pesanan dari pelanggan yang rutin melakukan order. Promosi dan penjualan juga dilakukan melalui sistem online, biasanya melalui website, blog dan facebook.Produk yang mereka buat pun telah lama memasuki pasar luar seperti Australia, New, Zealand dan Spanyol. Informan D (38 tahun) dan informan E (40 tahun) yang telah lama bekerja di yayasan ini menceritakan 
pada penulis. Informan D(38 tahun) yang merupakan anggota YPCM yang bertugas di bagian penjulan menuturkan:

"Di sini kan kadang sepi kadang rame kalau di showroom, kalau musim liburan itu ya lumayan lah rame karena kan banyak wisatawan. Kalau hari-hari biasa ya dari Jogja sendiri. Kadang orang ya lihat dari internet itu terus kan dijual online juga toh, terus ya orang-orang biasa dateng ke sini beli. Yang pesennya rutin itu ya selain dari sekolah-sekolah sekitar Jogja itu ada dari Sulawesi, mereka pesannya banyak itu katanya di sana dijual lagi"'(D, 38 tahun)

Konsumen YPCM tidak hanya datang dari Jogja saja. Banyaknya konsumen yang datang dari luar Jogja maupun mancanegara tersebut karena ketertarikan mereka pada keunikan desain produk yang dibuat oleh YPCM. Produk-produk yang ditawarkan memang sangat beragam dan banyak sekali jenisnya.Selain desain yang unik, kualitas produk yang dihasilkan juga sangat diperhatikan.Semua produk dibuat menggunakan kayu mahoni dan cat yang digunakan pun adalah cat anti toxic karena YPCM sangat mengutamakan keamanan bagi customer apalagi produk yang mereka buat kebanyakan mainan untuk anak-anak. Hasil dari penjualan yang didapat dari pembuatan produk kreatif tersebut digunakan untuk operasional, dibelanjakan kebutuhan bahan dan untuk gaji para anggota yayasan yang ikut bekerja.

\section{Pembahasan}

Peran Yayasan Penyandang Cacat Mandiri sebagai pendamping dalam pemberdayaan kelompok difabel di bidang ekonomi kreatif yaitu sebagai motivator, pada proses pendampingan ini anggota YPCM yang telah senior atau memiliki pengalaman lebih lama mencoba menggali potensi sumber daya yang dimiliki oleh rekanrekan difabel yang baru bergabung atau belajar. Kemudian mereka mengembangkan kesadaran diri tiap anggotanya agar dapat terbuka terhadap permasalahan yang dihadapi. Selain itu, sebagai pendamping, anggota yang telah senior juga menjadi komunikator, mereka menjadi tempat untuk berbagi informasi dan mampu membantu rekan difabel melaksanakan berbagai program atau pekerjaan di yayasan. Anggota YPCM juga menjadi fasilitator yang mendampingi rekan difabel dengan melakukan pengarahan seperti membantu dalam proses produksi produk kreatif dengan mengenalkan cara-cara penggunaan alat dan mengajari teknik-teknik membuat kerajinan. Apabila rekan difabel mengalami kesulitan, setiap anggota yayasan selalu mendiskusikannya dan saling membantu satu sama lain.

Selain sebagai pendamping, pihak YPCM juga memberikan pelatihan. Pelatihan merupakan salah satu bentuk pemberdayaan yang sangat diutamakan karena diharapkan mampu memberdayakan penyandang disabilitas di YPCM. Jenis pelatihan yang dilakukan yaitu pelatihan menjahit dan keterampilan bahasa inggris khususnya, lebih diutamakan pada mereka yang belum pernah mendapat pelatihan sama sekali sebelumnya. Bentuk pelatihan ini biasanya diberikan pada penyandang disabilitas yang dititipkan oleh lembaga-lembaga yang bekerjasama dengan YPCM maupun oleh keluarganya. Sedangkan bagi penyandang disabilitas yang sedang magang dan sebelumnya sudah pernah mendapat pelatihan di tempat lain, mereka lebih diarahkan ke dalam usaha milik YPCM. Namun, apabila mereka ingin mengikuti jenis pelatihan yang berbeda juga diperbolehkan.

Pelatihan awal yang diberikan oleh YPCM dilakukan selama kurang lebih dua hingga tiga bulan. Pelatihan yang diadakan bermanfaat dan menghasilkan nilai jual suatu produk yang dihasilkan. Jenis produk ekonomi kreatif yang dihasilkan dari pelatihan yaitu mainan edukatif., custom order dan menjahit. Produk custom order yang biasa dipesan oleh konsumen yaitu diantaranya produk-produk furniture, hiasan rumah, atau benda-benda lain berbahan dasar kayu. Produk lain yang pernah dihasilkan produk menjahit $\mathrm{p}$ yang dibuat dengansebagian menggunakan bahan tekstil.

Untuk pemasaran produk selain dijual melalui showroom yang juga berada di area gedung YPCM, produk yang mereka buat juga dititipkan di toko-toko sekitar Yogyakarta dengan system konsinyasi. Untuk produk yang dipasarkan ke luar pulau pada umumnya memang sudah pesanan dari pelanggan yang rutin melakukan order. Promosi dan penjualan juga dilakukan melalui sistem online, biasanya melalui website, blog dan facebook.Produk yang mereka buat pun telah lama memasuki pasar luar seperti Australia, New, Zealand dan Spanyol.Hasil dari penjualan yang didapat dari pembuatan produk kreatif tersebut digunakan untuk operasional, dibelanjakan kebutuhan bahan dan untuk gaji para anggota yayasan yang ikut bekerja. 


\section{PENUTUP}

\section{Kesimpulan}

Peran Yayasan Penyandang Cacat Mandiri sebagai pendamping dalam pemberdayaan kelompok difabel di bidang ekonomi kreatif yaitu sebagai motivator dan fasilitator. Peranan sebagai motivator yaitu memberikan berbagai macam bentuk dorongan yang mampu memberi energy positif dandapat membangkitkan kepercayaan diri difabel. Peranan sebagai fasilitator yaiitu memberikan memberikan pelatihan dan mewadahi kemampuan difabel setelah mengikuti pelatihan seperti turut menghasilkan nilai jual produk ekonomi kreatif untuk membantu ekonomi mereka.

\section{Saran}

Setelah melakukan penelitian ini, saran yang dapat digunakan oleh Yayasan Penyandang Cacat Mandiriyaitu yayasan diharapkan dapat menjalin banyak kerjasama dengan banyak instansi sebagai mitra kerja dan pihak yayasan diharapkan menambah jumlah pekerja tidak tetap pada saat jumlah order atau permintaan banyak.

\section{DAFTAR PUSTAKA}

Adi, Isbandi Rukminto. 2003. Pemberdayaan Pengembangan Masyarakat dan Intervensi Komunitas. Jakarta: Lembaga Penerbit Fakultas Ekonomi Universitas Indonesia

Tesoriero, Jim \& Ife Frank. 2008. Community Development. Yogyakarta: Pustaka Pelajar

Coleridge, Peter. 1997. Pembebasan dan Pembangunan, Perjuangan Penyandang Cacat di Negara-negara Berkembang. Yogyakarta; Pustaka Pelajar 